\title{
Adopter Categories in Respect to a Transplanted Monsoon Rice Variety in Two Selected Villages of Bangladesh
}

\author{
Modabber Ahmed Khan ${ }^{1,2}$, Kwang-Hwa Jeong ${ }^{2}$, A. S. M. Ziaul Karim ${ }^{1}$, Eun-Jong Kim² \& Muttaquinur Rahman ${ }^{1}$ \\ ${ }^{1}$ Department of Agricultural Extension Education, Bangladesh Agricultural University, Mymensingh, Bangladeh \\ ${ }^{2}$ Animal Environment Division, National Institute of Animal Sciece, RDA, Suwon, Republic of Korea \\ Correspondence: Modabber Ahmed Khan, Animal Environment Division, National Institute of Animal Sciece, \\ RDA, Suwon 441-706, Republic of Korea. Tel: 82-31-290-1716. E-mail: khan023@rda.go.kr
}

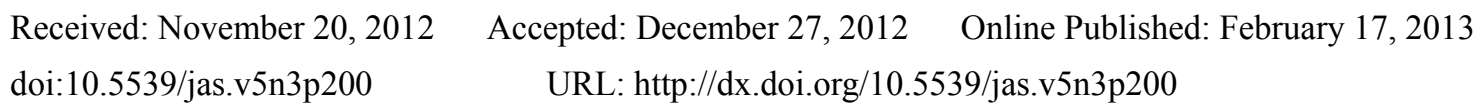

\begin{abstract}
The purpose of this study was to determine and describe the extent of adoption, innovativeness and adopter categories in respect to a transplanted monsoon rice variety (TMRV) growers. Attempts were also made to explore the relationships of five selected attributes of TMRV and 15 selected characteristics of TMRV growers with the growers' adoption and innovativeness. A total of 106 Binasail (is known as T. aman or monsoon variety) growers were selected randomly from 480 farm family heads of two selected villages of Bangladesh. Personal interview schedule was used for collecting data. The findings revealed that majority $(59 \%)$ of the Binasail growers had medium adoption towards Binasail while $26 \%$ had high and $15 \%$ had low adoption. In addition, $72 \%$ of the Binasail growers had medium innovativeness, as compared to $17 \%$ and $11 \%$ having high and low innovativeness, respectively. In case of adopter categorizations, $5 \%$ of the adopter farmers were innovators, $12 \%$ early adopters, $35 \%$ in early majority, $37 \%$ in the late majority and $11 \%$ were laggards in respect to adoption of Binasail rice. Correlation analyses indicate that the few attributes of Binasail rice had significant and positive relationship with the adoption of Binasail rice by the farmers, while all the five selected attributes were significantly and positively associated with innovativeness of the farmers. Findings further showed that the characteristics of the farmers such as age, education, farm size, contact with block supervisor (BS), mass contact, cosmopoliteness, organizational participation and attitude towards Binasail had significant and positive relationship with their adoption of Binasail rice. It was also found that farmers' education, farm size, contact with BS, organizational participation and attitude towards Binasail were significantly and positively accompanied with their innovativeness in respect to Binasail rice.
\end{abstract}

Keywords: adopter, categorization, Binasail, village

\section{Introduction}

Bangladesh is mainly an agro-based developing country where agriculture has been viewed as a fundamental contributor to the economy. About $85 \%$ of the total population live in rural areas and engaged in a wide range of agricultural activities both directly and indirectly. The contribution of agriculture sector in Gross Domestic Product (GDP) is $22 \%$ (BER, 2008). In the agriculture sector, the crop sub-sector dominates with $14.3 \%$ in GDP of which rice itself contributes about $53 \%$. Although $63 \%$ of labor force is directly engaged in agriculture and $78 \%$ of total crop is devoted to rice production, the country has still a chronic shortage of food-grain (BBS, 2010). In Bangladesh, rice contributes more than $80 \%$ of the total food supply where more than $95 \%$ of total population consumes rice, which provides $76 \%$ of calorie and $66 \%$ of total protein requirement of daily food intake (Bhuiyan et al., 2002). The importance of agriculture, especially the crop sector, to the economy of Bangladesh needs no emphasizing. The government has, therefore accorded the highest priority to make this sector commercially profitable, technically feasible and environmentally sound one.

World production of rice increased at a higher rate. But still millions of Asians and Africans do not get two morsel of food, which is constituted by rice as the first or second major item in their daily meals. World scientists and researchers are in the uphill struggle to avert a collision between rice production and population growth. Recent projections indicate that the world will need about 880 million tons of rice in 2025 (Lantin, 1999). Thus, to meet this increasing demand of rice, new technology is needed to move across the rice ecosystem. Large scale adoption of modern rice technology increased production, which helped scale adoption 
of modern rice technology increased production that also helped the country in achieving food at lower prices. Thus farmers of Bangladesh need to increase national productivity level closer to those already achieved in such developing countries. This is possible only when the farmers adopt modern rice production technologies to a much greater extent following intensive cultivation.

To meet-up food deficiency, various agricultural research institutes are working to develop modern variety (hardware) and new technique (software). Farmers often need to know techniques of cultivation, fertilizer application, etc. to ensure optimal production by the new variety. They may also play an important role in developing right kind of software. Scientists who develop new hardware in their research station should take into account the software, which might be available to farmers. Many innovations are continuously improved using farming experience and new research findings. Therefore, farmers could benefit themselves with these improvements by adopting the innovations. Some innovations are adopted more rapidly than others because the farmers perceive them to have favorable characteristics that are important for their adoption decision.

Efforts are being made to increase the production of rice in Bangladesh by introducing high yielding varieties (HYVs) of rice and providing improved cultural practices. The Department of Agriculture Extension (DAE) of Bangladesh is working to develop this sector by educating the farmers for better diffusion of HYV of rice and making the country self-sufficient in rice production. Based on seasonal classification, there are three types of rice crop, mainly Aus (April-August), Transplanted monsoon or aman (August-December) and Boro (January-June) which are grown in Bangladesh. On the basis of acreage and production Transplanted aman (T. aman) is the major rice crop of the country, which covers about $38 \%$ of the total rice crop area. Areas on which $\mathrm{T}$. aman is grown are comparatively free from the devastation by flood. Thus, $\mathrm{T}$. aman provides a major potential in improving the food situation of the country. Considering the situation, various steps have been taken to gear up rice production.

Binasail is known as T. aman or monsoon variety, which was developed from a popular indigenous variety Naizersail (a strongly photosensitive variety) through application of gamma radiation by the Bangladesh Institute of Nuclear Agriculture (BINA). Rice grain of Binasail is fine and as tasty as Nizersail. Farmers can get more straw for fodder and fuel. Low insect and disease infestation on Binasail produce higher grain yield. Resource poor as well as resource-rich farmers can cultivate Binasial because it requires low input than any other HYVs. Relatively less sensitive to photoperiod Binasial made more chance for late cultivation without decreasing grain yield. The mutant variety Binasail, when timely planted (July-August), matured about 3 weeks earlier and had a $20 \%$ higher grain yield than the mother variety Naizersail. The variety also had higher protein content than the mother variety. As Binasail is an innovation, it should meet as far as possible the following characteristics: (a) Relative advantage, (b) Compatibility, (c) Complexity, (d) Trialability, and (e) Observability. Since its release, the DAE and the Bangladesh Agricultural University Extension Centre (BAUEC) have been engaged to diffuse the variety among the farmers through extension programs.

The success of any technology depends on its dissemination among the potential users, which ultimately is measured by the level of adoption of the technology. It is assumed that notable improvements can take place in Bangladesh agriculture, if the available BINA technology is accepted and adopted by the farmers. Among the BINA technology, Binasail is quite suitable for the sustainable agricultural development of Bangladesh. To our knowledge, there was no research conducted about farmers' adoption, innovativeness and adopter categories in respect to Binasail rice. In order to prepare programs and courses of action for wider adoption of Binasail rice, it is necessary to have a clear understanding of the present position in respect to Binasail rice by the farmers. It is also necessary to have an understanding of the adopter categories of Binasail rice. An understanding of the relationships of the farmers' adoption and innovativeness with the attributes of Binasail rice and farmers' selected characteristics will be helpful to the planners and extension workers. However, the objectives of this study were (a) to determine and describe the extent of adoption, the extent of innovativeness and also the adopter categories in respect of Binasail rice; (b) to determine and describe the selected attributes of Binasail rice as perceived by the Binasail rice growers; (c) to determine and describe the selected characteristics of Binasail rice growers; (d) to explore the relationship of Binasail rice growers' adoption and innovativeness with selected attributes and selected characteristics of Binasail rice growers; and (e) to identify the reasons for adoption of Binasail rice as opined by the Binasail rice growers. 


\section{Materials and Method}

\subsection{Locale of the Study}

Two villages namely Shuhila and Ghagra under Mymensingh district of Bangaldesh were the locale of the study. These two villages were selected because they were located relatively in the neighborhood of Bangladesh Agricultural University (BAU) and BINA; and the communication facility between these institutions and the study area are good. Binasail rice variety was introduced in the study area in the year of 1992, which indicated a reasonable period of time to facilitate the present study. The maps of Mymensingh district showing Mymensingh sadar upazila, and Mymensingh sadar upazila showing the study area are shown in Figure 1.
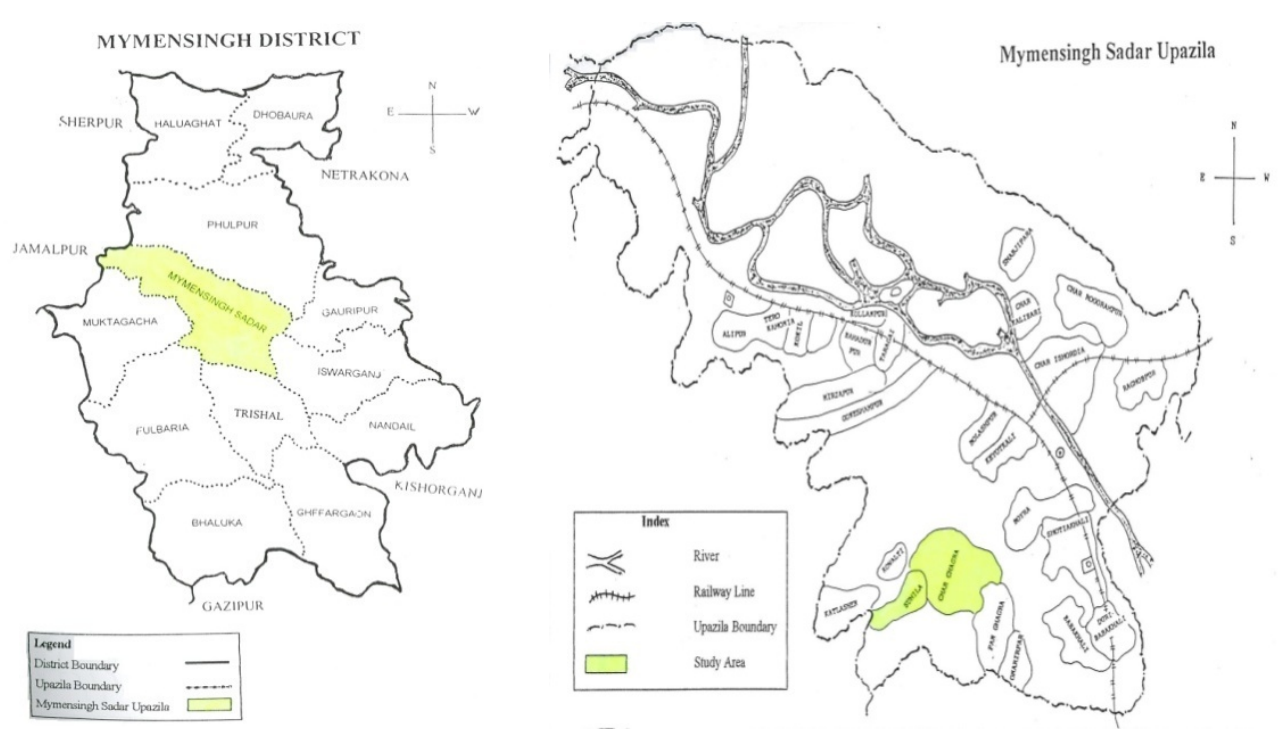

Figure 1. Maps of Mymensingh district showing Mymensingh sadar upazila, and Mymensingh sadar upazila showing the study area

\subsection{Population and Sample}

An up-to-date list of all Binasail rice farm family heads of Shuhila and Ghagra villages was prepared with the help of local block supervisor (BS). The 480 farm family heads of these two villages thus listed constituted the population for this study. Thereafter, $22 \%$ of the farm family heads were randomly selected from each village so as to constitute a sample of 106. This sample was used for collection of data for the study. Moreover, a reserve list of 11 farm family heads was prepared. The reserve listed farmers were used when the farmers under the original sample were not available during actual data collection. The distribution of population and sample of Binasail rice growers along with the reserve-listed growers are shown in Table 1.

Table 1. Distribution of population and sample of Binasail rice growers

\begin{tabular}{cccc}
\hline Name of village & Population of farmers & Sample of farmers & Reserve listed farmers \\
\hline Shuhila & 230 & 51 & 5 \\
Ghagra & 250 & 55 & 6 \\
Total & $\mathbf{4 8 0}$ & $\mathbf{1 0 6}$ & $\mathbf{1 1}$ \\
\hline
\end{tabular}

\subsection{The Research Instrument}

For the purpose of data collection, an interview schedule was prepared. It was prepared keeping the objectives of the study in mind. The schedule contained both open and closed form of questions. Simple and direct questions and some scales were included in the schedule to collect data on adopter categories in respect to Binasail and relevant matters. Appropriate scales were also developed to operationalize some selected characteristics of the farmers. The draft schedule was prepared and pre-tested. For pre-test purpose, 16 farmers from the study area 
were interviewed by using the interview schedule. Based on the pre-test experience, necessary corrections, additions, alternations and rearrangements were made in the schedule. Thus the schedule was prepared for final use. The interview schedule (Questionnaire) was consisted of basic information regarding farmers; their knowledge on Binasail; farm size; annual income from different sources; contact with BS, BINA personnel, BAUEC personnel, group and mass contact; cosmopoliteness; organizational participation; opinion leadership; attitude towards Binasail; characteristics of Binasail rice; adoption of Binasail rice; reasons for adoption and also the reasons of intervals for adoption of Binasail technology. However, a total of 106 Binasail growers were selected randomly from 480 farm family heads of the villages.

\subsection{Data Collection}

Data were collected by means of interview of sampled farmers. Before going to the respondent farmers for interview, they were informed verbally to ensure their availability. The places were usually mentioned for the respondent's residence and desired rapport was made with the respondents, however, if any respondent failed to understand any questions, proper care had taken to explain the issue. Excellent co-operation and co-ordination were obtained from all respondents who were concerned in the field during data collection. Only a single interview was carried out with each farmer and thus a great reliance was placed on the ability of farmers to recall the relevant information.

\subsection{Data Processing and Analysis}

The collected raw data were examined thoroughly to find out the errors and omissions. Various statistical measures such as number and percentage distribution, range, mean, standard deviation and rank order were used for describing the extent of adoption of Binasail and extent of innovativeness in respect to Binasail rice growers. In case of qualitative data, appropriate scoring technique was followed to convert the data into quantitative forms. These were then tabulated according to the objectives of the study. For exploring the relationships between the dependent variable and the selected characteristics of Binasail rice growers and Binasail rice attributes, Pearsons' Product Moment Correlation (r) was computed. A 5\% level of probability was used as a basis to accept or reject any null hypothesis.

\subsection{Variables}

This study was concerned with adoption and innovativeness of Binasail growers as dependent variables and the selected attributes of Binasail rice and the selected characteristics of the Binasail growers as independent variables. It was therefore, necessary to limit the attributes of Binasail rice and farmers' characteristics. The attributes included: relative advantage, compatibility, complexity, trialability and observability. The characteristics were: age, education, family size, knowledge on Binasail, farm size, annual income, contact with BS, contact with BINA personnel, contact with BAUEC personnel, group contact, mass contact, cosmpoliteness, organizational participation, opinion leadership and attitude toward Binasail.

\subsection{Measurement of Dependent Variables}

Adoption of Binasail rice was measured by computing a composite Binasail adoption score. This score was based on two dimensions like size of area on which Binasail rice was adopted by an individual and the duration during which period of time Binasail rice was adopted. Two subscores i.e. area sub-score and duration sub-score were computed for the said dimensions. Area sub-score was determined on the basis of the land area has been used by an individual for adoption of the Binasail rice. Scoring was made for it where possible area sub-score for a farmer could vary from 1 to 4 and it was assumed that the higher the area sub-score, the higher will be the adoption. Duration sub-score was computed on the basis of the period during which an individual adopted the Binasail rice in the study area. Scoring was also made here (1-4) and the two sub-scores were added together to obtain composite Binasail adoption score of an individual. Therefore, the possible composite adoption score of a farmer could range from 1 to 8 while 1 indicating very low and 8 for very high adoption. It was finally assumed that the higher the composite Binasail adoption score, the greater will be the overall adoption of Binasail rice.

In case of innovativeness, it was considered as the degree to which a respondent farmer was relatively earlier in adopting Binasail rice. This variable was measured on the basis of how many years were taken to adopt the Binasail rice after being informed for the first time. So, the possible innovativeness score of a respondent could range from 1 to 9 , while 1 indicated very low innovativeness and 9 very high. Binasail was first introduced in the study year in 1992; therefore, the maximum duration period of adoption was nine years up to data collection. 


\subsection{Measurement of Independent Variables}

The selected characteristics of the respondent farmers as well as selected attributes of Binasail rice constituted the independent variables of the study. To keep the work within the manageable sphere, 20 independent variables were selected for the study. A brief description of the scoring methods is presented in Table 2.

Table 2. Scoring method and possible scores of independent variables

\begin{tabular}{lll}
\hline Independent variable & Scoring method & Possible score \\
\hline Age & No. of years & Unknown \\
Education & Years of schooling & Unknown \\
Family size & No. of members in the family & Unknown \\
Knowledge on Binasail & Score & $0-20$ \\
Farm size & Hectare & Unknown \\
Annual income & USD & Unknown \\
Contact with BS & Score & $0-5$ \\
Contact with BINA personnel & Score & $0-25$ \\
Contact with BAUEC personnel & Score & $0-20$ \\
Group contact & Score & $0-20$ \\
Mass contact & Score & $0-25$ \\
Cosmopoliteness & Score & $0-25$ \\
Organizational participation & Score & $0-72$ \\
Opinion leadership & Score & $0-30$ \\
Attitude toward Binasail & Score & $0-48$ \\
Relative advantage & Score & $0-20$ \\
Compatibility & Score & $0-22$ \\
Complexity & Score & $0-4$ \\
Trialability & Score & $0-4$ \\
Observability & Score & $0-10$ \\
\hline
\end{tabular}

\section{Results and Discussion}

\subsection{Farmers' Adoption of Binasail Rice}

Adoption of Binasail rice by the farmers is the decision to continue full use of the innovation. Binasail rice adoption referred to the adoption of Binasail rice where the individual himself took the decision and implemented the decision by using Binasail rice. In the study area, Binasail rice was adopted by the individuals themselves and the decision to adopt the innovation was entirely dependent on the individuals. Hence, the present study dealt with individual adoption. Composite Binasail rice adoption was determined for each respondent Binasail farmer by computing a composite Binasail rice adoption score for each of them. The lowest possible adoption score that a respondent obtained was 0 to the highest 8 .

The computed Binasail rice adoption scores, however, ranged from 3 to 8 , the mean and standard deviation being 6.16 and 1.45, respectively (Table 3). In order to facilitate description of Binasail rice adoption it was necessary to categories the farmers. Since the data were almost normally distributed, mean and standard deviation was used for categorization. The respondents were classified into three categories as shown below.

Table 3. Classification of the Binasail rice farmers' according to their extent of adoption of Binasail.

\begin{tabular}{ccccc}
\hline \multirow{2}{*}{ Categories according to adoption } & \multicolumn{2}{c}{ Farmers $(\mathrm{N}=106)$} & Mean & S.D. \\
\cline { 2 - 5 } & Number & Percentage & & \\
\hline Low adoption & 16 & 15 & & \\
Medium adoption & 62 & 59 & 6.16 & 1.45 \\
High adoption & 28 & 26 & & \\
Total & $\mathbf{1 0 6}$ & $\mathbf{1 0 0}$ & & \\
\hline
\end{tabular}


Table 3 shows that the largest proportion (59\%) of the farmers had medium adoption as compared to $26 \%$ having high adoption. Only $15 \%$ of the farmers had low adoption for Binasail rice. Such a situation regarding adoption of Binasail rice by the farmers did not provide a gloomy picture, but still there existed a large gap between what is and what ought to be.

\subsection{Farmers' Innovativeness Regarding Binasail Rice}

In the present study, innovativeness referred to the degree to which a farmer was relatively earlier in adopting Binasail rice. As a matter of fact, all the farmers' included in the sample were Binasail rice growers. Since Binasail rice was first adopted in the study area in 1992, the highest adoption period for the farmers in respect to Binasail rice was nine years.

The possible innovativeness scores of the farmers regarding Binasail rice could range from 1 to 9 , while 1 indicated very low innovativeness and 9 indicating very high innovativeness. However, the observed innovativeness scores of the farmers regarding Binasail rice ranged from 1 to 9, the mean being 5.58 and the standard deviation 1.87 (Table 4). On the basis of their innovativeness scores, the Binasail rice farmers were classified into the following categories:

Table 4. Classification of the Binasail rice farmers according to their extent of innovativeness regarding Binasail rice

\begin{tabular}{|c|c|c|c|c|}
\hline \multirow{2}{*}{ Categories according to innovativeness } & \multicolumn{2}{|c|}{ Farmers $(\mathrm{N}=106)$} & \multirow[t]{2}{*}{ Mean } & \multirow[t]{2}{*}{ S.D. } \\
\hline & Number & Percent & & \\
\hline Low innovativeness & 12 & 11 & \multirow{4}{*}{5.58} & \multirow{4}{*}{1.87} \\
\hline Medium innovativeness & 76 & 72 & & \\
\hline High innovativeness & 18 & 17 & & \\
\hline Total & 106 & 100 & & \\
\hline
\end{tabular}

Data in Table 4 reveals that about three-fourth $(72 \%)$ of the farmers had medium innovativeness for Binasail rice as compared to $17 \%$ having high innovativeness and $11 \%$ having low innovativeness. As majority of the farmers in the study area possessed medium to high innovativeness for Binasail rice, there is a possibility exists to improve agricultural production of the farmers through awareness.

\subsection{Adopter Categories}

The individuals having adopted in a social system may be classified into several categories on the basis of their innovativeness. These classifications of the adopters are called adopter categories. Rogers (1983) had set five categories for describing the adopters. These five categories may be regarded as ideal types, which were conceptualizations based on observations of reality and were designed to institute comparison. However, the categories were innovators, early adopters, early majority, late majority and laggards.

An individual usually does not accept an innovation immediately upon hearing about it. However, the adoption of an innovation requires a decision by an individual. In the present study, it is shown that the distribution of Binasail rice adopters over a period of nine years closely approached normality (Table 5). Here, it may be mentioned that Binasail rice introduced in the study area by means of different extension methods.

The distribution of Binasail adopters presented in Table 5 might be explained by the statistical concept of normal curve. However, the distribution of the adopter was partitioned into five adopter categories by using the mean and standard deviation.

Data in Table 6 indicates that the area lying to the left of the mean time of adoption minus two standard deviations $(\bar{X}-2 \mathrm{SD})$ included $5 \%$ of the individuals who were towards the beginning to adopt Binasail rice. They could be known as innovators. The next $13 \%$ of the individuals between the mean minus one standard deviation $(\bar{X}-\mathrm{SD})$ and the mean minus two standard deviations $(\bar{X}-2 \mathrm{SD})$ to adopt Binasail rice were called as early adopters. The next $35 \%$ of the adopters, called early majority, were included in the area between the mean time of adoption $(\bar{X})$ and the mean minus one standard deviation $(\bar{X}-\mathrm{SD})$. Between the mean $(\bar{X})$ and the mean plus one standard deviation $(\bar{X}+\mathrm{SD})$ to right of the mean are located in the next $37 \%$ to adopt the innovation (Binasail) i.e. the late majority. The last $12 \%$ to the right of the mean plus one standard deviation 
$(\bar{X}+\mathrm{SD})$ were the last to adopt Binasail rice, and they were known as laggards. However, for having a better understanding, Figure 2 could be seen.

Table 5. Number and percentage distribution of the adopters of Binasail rice

\begin{tabular}{ccc}
\hline \multirow{2}{*}{ Name of year } & \multicolumn{3}{c}{ Adopters of Binasail rice } \\
\cline { 2 - 3 } & Number & Percent \\
\hline $1993\left(1^{\text {st }}\right.$ year $)$ & 5 & 4.7 \\
$1994\left(2^{\text {nd }}\right.$ year $)$ & 13 & 12.3 \\
$1995\left(3^{\text {rd }}\right.$ year $)$ & 17 & 16 \\
$1996\left(4^{\text {th }}\right.$ year $)$ & 20 & 18.9 \\
$1997\left(5^{\text {th }}\right.$ year $)$ & 22 & 20.8 \\
$1998\left(6^{\text {th }}\right.$ year $)$ & 17 & 16 \\
$1999\left(7^{\text {th }}\right.$ year $)$ & 5 & 4.7 \\
$2000\left(8^{\text {th }}\right.$ year $)$ & 4 & 3.8 \\
$2001\left(9^{\text {th }}\right.$ year $)$ & 3 & 2.8 \\
Total & $\mathbf{1 0 6}$ & $\mathbf{1 0 0}$ \\
\hline
\end{tabular}

${ }^{\text {Note }}$ no discontinuation of Binasail cultivation over a period of nine years in the study area

Table 6. Classification of the Binasail rice farmers according to their adopter categories

\begin{tabular}{ccc}
\hline Type of categories & \multicolumn{2}{c}{ Farmers $(\mathrm{N}=106)$} \\
\cline { 2 - 3 } & Number & Percent \\
\hline Innovators (within 1 year) & 5 & 5 \\
Early adopter (within 2 years) & 13 & 12 \\
Early majority (within 4 years) & 37 & 35 \\
Late majority (within 6 years) & 39 & 37 \\
Laggards (within 9 years) & 12 & 11 \\
Total & $\mathbf{1 0 6}$ & $\mathbf{1 0 0}$ \\
\hline
\end{tabular}

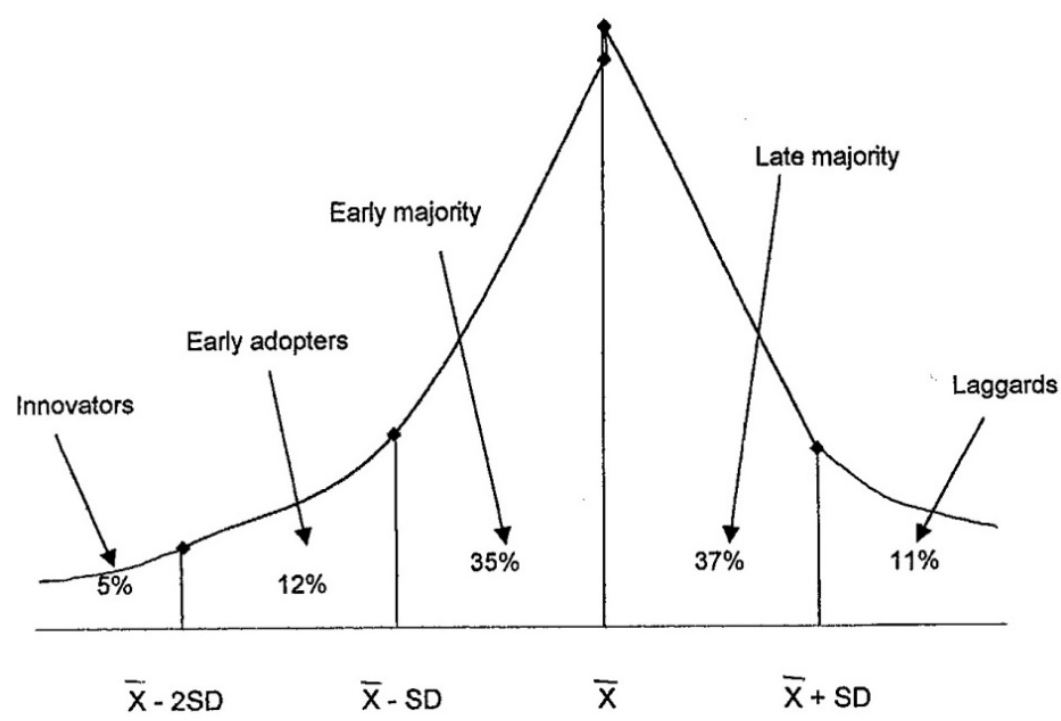

Figure 2. Unstandardized adopter categorization on the basis of farmers' innovativeness regarding Binasail rice 
Figure 2 shows the adopter categories of the farmers regarding Binasail rice in two selected villages. In this figure, a slightly unequal proportion of the farmers between the two categories, namely, early majority and late majority are visible. But, such types of unequal proportions were non-existent in Roger's model of adopter categories. In the present study, it was probably due to the data, which were slightly deviated from the normal distribution. However, due to the existence of unequal proportions (early majority $35 \%$ and late majority $37 \%$ ), we considered the mean value of the two proportions (35\% and 37\%) as 36. After taking mean time of adoption of Binasail rice, Figure 3 has been drawn. This figure showing adopter categorization on the basis of innovativeness of the farmers regarding Binasail rice is very close to the idea of Roger's adopter categories model.
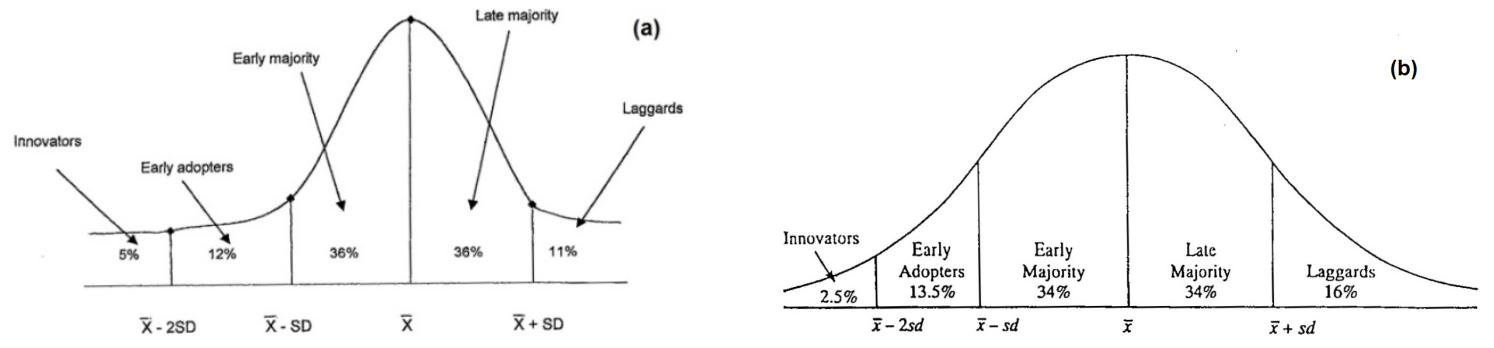

Figure 3. Standardized adopter categorization on the basis of farmers' innovativeness regarding Binasail rice (a); Adopter categorization based on innovativeness, adopted from Rogers, 1983(b)

\subsection{Selected Attributes of Binasail Rice}

\subsubsection{Relative Advantage}

The Binasail farmers were classified into three categories on the basis of their relative advantage score as shown in Table 7. However, the observed relative advantage score for Binasail rice as perceived by the Binasail farmers ranged from 12 to 19 against the possible range of 0 to 20 , the mean being 14.71 with the standard deviation of 1.46. It is seen that most ( $89 \%)$ of the Binasail farmers perceived medium to low relative advantage for Binasail rice. The highest proportion (67\%) of the respondents perceived medium relative advantage for Binasail rice, while $22 \%$ perceived low relative advantage and $11 \%$ high.

\subsubsection{Compatibility}

Data contained in Table 7 shows that a total of $63 \%$ of the respondents observed medium compatibility for Binasail rice, followed by $22 \%$ and $15 \%$ as high and low, respectively. However, $85 \%$ of the respondents perceived medium to high compatibility.

\subsubsection{Complexity}

The complexity score ranged from 2 to 4 with an average of 3.27 with the standard deviation 0.57 (Table 7). However, the complexity score of Binasail farmers in terms of their scores regarding complexity of Binasail rice were classified into three categories. It is seen that a major portion (94\%) of Binasail farmers perceived medium to high complexity for Binasail rice. In addition, the three-fifth $(60 \%)$ of the respondents perceived medium complexity for Binasail, while $34 \%$ perceived high complexity.

\subsubsection{Trialability}

The trialability score for Binasail farmers in terms of scores regarding trialability of Binasail rice were classified into three categories (Table 7). It reveals that the largest proportion (56\%) of the Binasail farmers perceived medium trialability for Binasail rice, followed by $36 \%$ and $8 \%$ as low and high trialability, respectively.

\subsubsection{Observability}

The computed observability score for Binasail rice ranged from 5 to 9 , the mean being 6.64 and the standard deviation 1.08 (Table 7). It shows that the $62 \%$ of the Binasail farmers perceived medium observability, while $24 \%$ perceived high observability and $14 \%$ low observability for Binasail rice. As a lion section, $86 \%$ of the Binasail growers perceived medium to high observability for Binasail rice. 
Table 7. Salient features of the selected attributes of Binasail rice

\begin{tabular}{|c|c|c|c|c|c|c|c|c|}
\hline \multirow{2}{*}{$\begin{array}{l}\text { Attributes of Binasail rice } \\
\text { (Independent variables) }\end{array}$} & \multirow{2}{*}{$\begin{array}{l}\text { Scoring } \\
\text { method }\end{array}$} & \multirow{2}{*}{$\begin{array}{l}\text { Possible } \\
\text { scores }\end{array}$} & \multirow{2}{*}{$\begin{array}{c}\text { Observed } \\
\text { scores }\end{array}$} & \multirow{2}{*}{ Categories } & \multicolumn{2}{|c|}{$\begin{array}{l}\text { Respondents } \\
\qquad(\mathrm{N}=106)\end{array}$} & \multirow{2}{*}{ Mean } & \multirow{2}{*}{ S.D. } \\
\hline & & & & & Number & Percent & & \\
\hline \multirow[t]{4}{*}{ Relative advantage } & Score & $0-20$ & $12-19$ & Low (below 13.25) & 23 & 22 & 14.71 & 1.46 \\
\hline & & & & Medium & 71 & 67 & & \\
\hline & & & & $(13.25-16.17)$ & 12 & 11 & & \\
\hline & & & & High (above 16.17) & & & & \\
\hline \multirow[t]{4}{*}{ Compatibility } & Score & $0-22$ & $11-18$ & Low (below 12.58) & 16 & 15 & 14.25 & 1.67 \\
\hline & & & & Medium & 67 & 63 & & \\
\hline & & & & $(12.58-15.92)$ & 23 & 22 & & \\
\hline & & & & High (above 15.92) & & & & \\
\hline \multirow[t]{4}{*}{ Complexity } & Score & $0-4$ & $2-4$ & Low (below 2.70) & 7 & 6 & 3.27 & 0.57 \\
\hline & & & & Medium & 63 & 60 & & \\
\hline & & & & $(2.70-3.84)$ & 36 & 34 & & \\
\hline & & & & High (above 3.84) & & & & \\
\hline \multirow[t]{4}{*}{ Trialability } & Score & $0-4$ & $2-4$ & Low (below 2.11) & 38 & 36 & 2.72 & 0.61 \\
\hline & & & & Medium & 59 & 56 & & \\
\hline & & & & $(2.11-3.33)$ & 9 & 8 & & \\
\hline & & & & High (above 3.33) & & & & \\
\hline \multirow[t]{4}{*}{ Observability } & Score & $0-10$ & $5-9$ & Low (below 5.56) & 15 & 14 & 6.64 & 1.08 \\
\hline & & & & Medium & 66 & 62 & & \\
\hline & & & & $(5.56-7.72)$ & 25 & 24 & & \\
\hline & & & & High (above 7.72) & & & & \\
\hline
\end{tabular}

\subsection{Selected Characteristics of the Farmers}

Behavior of an individual is largely determined by his characteristics. These characteristics of an individual contribute to a great extent in the matter of shaping of his behavior. Therefore, the major hypothesis of the study was that the extent of adoption and innovativeness of the farmers in respect to Binasail rice would also be influenced by various characteristics of the farmers.

\subsubsection{Age}

The age of the responded Binasail farmers ranged from 20 to 68 years, the mean being 43.17 with the standard deviation 11.17. On the basis of their age, the farmers were classified into three categories namely young (upto 35 years), middle (36-55 years) and old aged (above 55 years). The highest proportion (59\%) of the respondents belonged to middle aged category as compared to $27 \%$ being young and $14 \%$ old (Table 8 ). This leads to understanding that the phenomena with regard to farmers' adoption and innovativeness regarding Binasail rice would be reflected more in the present study by the middle aged group. A major section (86\%) of the respondents were young and middle aged farmers, therefore, the development as well as extension agencies should pay a clear attention to the major section of the farmers who are perceptive and productive for the adoption of their technology. 
Table 8. Salient features of the selected characteristics of Binasail rice farmers

\begin{tabular}{|c|c|c|c|c|c|c|c|c|}
\hline \multirow[t]{2}{*}{ Variables } & \multirow{2}{*}{$\begin{array}{l}\text { Scoring } \\
\text { method }\end{array}$} & \multirow{2}{*}{$\begin{array}{l}\text { Possible } \\
\text { scores }\end{array}$} & \multirow{2}{*}{$\begin{array}{l}\text { Observed } \\
\text { scores }\end{array}$} & \multirow{2}{*}{ Categories } & \multicolumn{2}{|c|}{$\begin{array}{l}\text { Respondents } \\
(\mathrm{N}=106)\end{array}$} & \multirow[t]{2}{*}{ Mean } & \multirow[t]{2}{*}{ S.D. } \\
\hline & & & & & Number & Percent & & \\
\hline \multirow[t]{3}{*}{ Age } & \multirow[t]{3}{*}{ No. of years } & \multirow[t]{3}{*}{ Unknown } & \multirow[t]{3}{*}{$20-68$} & Young aged (upto 35) & 29 & 27 & \multirow[t]{3}{*}{43.17} & \multirow[t]{3}{*}{11.17} \\
\hline & & & & Middle aged (36-55) & 63 & 59 & & \\
\hline & & & & Old aged (above 55) & 14 & 14 & & \\
\hline \multirow[t]{6}{*}{ Education } & \multirow{6}{*}{$\begin{array}{l}\text { Years of } \\
\text { schooling }\end{array}$} & \multirow[t]{6}{*}{ Unknown } & \multirow[t]{6}{*}{$0-12$} & Illiterate $(0)$ & 15 & 14 & \multirow[t]{6}{*}{4.23} & \multirow[t]{6}{*}{3.20} \\
\hline & & & & Sign literate $(0.5)$ & 8 & 8 & & \\
\hline & & & & Primary level (1-5) & 48 & 45 & & \\
\hline & & & & Junior secondary & 26 & 25 & & \\
\hline & & & & literate (6-8) & 9 & 8 & & \\
\hline & & & & $\begin{array}{c}\text { Above junior } \\
\text { secondary literate }(9 \\
\text { or above) }\end{array}$ & & & & \\
\hline \multirow[t]{3}{*}{ Family size } & \multirow{3}{*}{$\begin{array}{l}\text { No. of } \\
\text { members in } \\
\text { the family }\end{array}$} & \multirow[t]{3}{*}{ Unknown } & \multirow[t]{3}{*}{$2-11$} & Small family (upto 4) & 38 & 36 & \multirow[t]{3}{*}{5.35} & \multirow[t]{3}{*}{1.66} \\
\hline & & & & Medium family (5-7) & 55 & 52 & & \\
\hline & & & & $\begin{array}{l}\text { Large family (above } \\
\text { 7) }\end{array}$ & 13 & 12 & & \\
\hline \multirow{4}{*}{$\begin{array}{l}\text { Knowledge on } \\
\text { Binasail }\end{array}$} & \multirow[t]{4}{*}{ Score } & \multirow[t]{4}{*}{$0-20$} & $10-16$ & Low knowledge & 15 & 14 & 13.76 & 1.16 \\
\hline & & & & (below 12.60) & 63 & 59 & & \\
\hline & & & & $\begin{array}{l}\text { Medium knowledge } \\
\quad(12.60-14.92)\end{array}$ & 28 & 27 & & \\
\hline & & & & $\begin{array}{l}\text { High knowledge } \\
\text { (above 14.92) }\end{array}$ & & & & \\
\hline Farm size & Hectare & Unknown & $0.34-1.21$ & Small farm (below & 13 & 12 & 0.80 & 0.14 \\
\hline & & & & $0.67)$ & 83 & 78 & & \\
\hline & & & & $\begin{array}{l}\text { Medium farm } \\
(0.67-0.95)\end{array}$ & 10 & 10 & & \\
\hline & & & & $\begin{array}{l}\text { Large farm (above } \\
0.95)\end{array}$ & & & & \\
\hline Annual income & USD & Unknown & $684-1258$ & Low income (below & 11 & 10 & 77565.09 & 8500.08 \\
\hline & & & & $852)$ & 83 & 79 & & \\
\hline & & & & $\begin{array}{l}\text { Medium income } \\
\quad(852-1062)\end{array}$ & 12 & 11 & & \\
\hline & & & & $\begin{array}{l}\text { High income (above } \\
1062 \text { ) }\end{array}$ & & & & \\
\hline Contact with BS & Score & $0-5$ & $1-5$ & Low contact (below & 22 & 21 & 3.50 & 1.14 \\
\hline & & & & $2.36)$ & 60 & 56 & & \\
\hline & & & & $\begin{array}{l}\text { Medium contact } \\
(2.36-4.64)\end{array}$ & 24 & 23 & & \\
\hline & & & & $\begin{array}{c}\text { High contact (above } \\
4.64 \text { ) }\end{array}$ & & & & \\
\hline Contact with BINA & Score & $0-25$ & $0-4$ & No contact $(0)$ & 30 & 28 & 0.93 & 0.78 \\
\hline personnel & & & & $\begin{array}{c}\text { Some contact (above } \\
0 \text { ) }\end{array}$ & 76 & 72 & & \\
\hline
\end{tabular}




\begin{tabular}{|c|c|c|c|c|c|c|c|c|}
\hline Contact with & Score & $0-20$ & $0-7$ & No contact (0) & 42 & 40 & 1.01 & 1.26 \\
\hline BAUEC personnel & & & & $\begin{array}{c}\text { Some contact (above } \\
0 \text { ) }\end{array}$ & 64 & 60 & & \\
\hline \multirow[t]{4}{*}{ Group contact } & \multirow[t]{4}{*}{ Score } & \multirow[t]{4}{*}{$0-20$} & \multirow[t]{4}{*}{$1-12$} & Very low (below & 17 & 16 & \multirow[t]{4}{*}{6.37} & \multirow[t]{4}{*}{1.92} \\
\hline & & & & $4.45)$ & 76 & 72 & & \\
\hline & & & & Low (4.45-8.29) & 13 & 12 & & \\
\hline & & & & Medium (above 8.29) & & & & \\
\hline \multirow[t]{5}{*}{ Mass contact } & \multirow[t]{5}{*}{ Score } & \multirow[t]{5}{*}{$0-25$} & \multirow[t]{5}{*}{$5-22$} & Low contact (upto 7) & 29 & 27 & \multirow[t]{5}{*}{9.16} & \multirow[t]{5}{*}{2.95} \\
\hline & & & & Medium contact & 72 & 68 & & \\
\hline & & & & $(8-14)$ & 5 & 5 & & \\
\hline & & & & High contact (above & & & & \\
\hline & & & & 14) & & & & \\
\hline \multirow[t]{6}{*}{ Cosmopoliteness } & \multirow[t]{6}{*}{ Score } & \multirow[t]{6}{*}{$0-25$} & \multirow[t]{6}{*}{$2-14$} & Low cosmopoliteness & 21 & 20 & \multirow[t]{6}{*}{8.38} & \multirow[t]{6}{*}{2.23} \\
\hline & & & & (below 6.15) & 69 & 65 & & \\
\hline & & & & $\begin{array}{c}\text { Medium } \\
\text { cosmonoliteness }\end{array}$ & 16 & 15 & & \\
\hline & & & & $(6.15-10.61)$ & & & & \\
\hline & & & & High cosmopoliteness & & & & \\
\hline & & & & (above 10.61) & & & & \\
\hline \multirow{5}{*}{$\begin{array}{l}\text { Organizational } \\
\text { participation }\end{array}$} & \multirow[t]{5}{*}{ Score } & \multirow[t]{5}{*}{$0-72$} & \multirow[t]{5}{*}{$2-17$} & Very low (below & 17 & 16 & \multirow[t]{5}{*}{7.0} & \multirow[t]{5}{*}{3.52} \\
\hline & & & & 3.48) & 70 & 66 & & \\
\hline & & & & Low (3.48-10.52) & 19 & 18 & & \\
\hline & & & & Medium (above & & & & \\
\hline & & & & $10.52)$ & & & & \\
\hline \multirow[t]{8}{*}{ Opinion leadership } & \multirow[t]{8}{*}{ Score } & \multirow[t]{8}{*}{$0-30$} & $0-28$ & No opinion leadership & 14 & 13 & 6.43 & 4.89 \\
\hline & & & & $(0)$ & 33 & 31 & & \\
\hline & & & & $\begin{array}{l}\text { Very low opinion } \\
\text { leadershin (unto 5) }\end{array}$ & 52 & 49 & & \\
\hline & & & & (20) & 7 & 7 & & \\
\hline & & & & Low opinion & & & & \\
\hline & & & & leadership (6-10) & & & & \\
\hline & & & & Medium opinion & & & & \\
\hline & & & & leadership (Above 10) & & & & \\
\hline Attitude toward & Score & $0-48$ & $19-37$ & Unfavourable attitude & 2 & 2 & 29.15 & 2.93 \\
\hline Binasail & & & & (upto 24) & 77 & 73 & & \\
\hline & & & & $\begin{array}{l}\text { Less favourable } \\
\text { attitude (25-30) }\end{array}$ & 27 & 25 & & \\
\hline & & & & Substantially & & & & \\
\hline & & & & favourable attitude & & & & \\
\hline & & & & (above 30) & & & & \\
\hline
\end{tabular}

\subsubsection{Education}

Table 8 shows that the farmers were classified into five categories according to their level of education. A total of $45 \%$ of the farmers was primary literate. In case of junior secondary level and above junior secondary level of education, the proportions were $25 \%$ and $8 \%$, respectively. The data also expressed that $8 \%$ of the farmers could sign only, while $14 \%$ were fully illiterate. Thus majority $(78 \%)$ of the farmers were found literate (from primary literate to above junior secondary literate). The findings also indicate that the farmers had higher literacy than the national average which is $56.8 \%$ (BBS, 2010). This may be due to inclusion of only male farmers in the present study. 
It is well known that an educated individual is likely to be more receptive to the modern facts and ideas. In addition, they have much mental strength in deciding on a matter related to problem solving or adoption of technologies in their everyday life. Thus, farming community in the study area may well be considered as a suitable ground for the adoption of technologies, or execution of change program whatever needed.

\subsubsection{Family Size}

The farmers were classified into three categories namely, small family (upto 4 members), medium family ( 5 to 7 members) and large family (above 7 members). However, Table 8 expressed that the highest proportion (52\%) of the farmers had medium family size as compared to $36 \%$ having small and $12 \%$ large family size. Thus, an over-whelming majority ( $88 \%$ ) of the farmers were found to have small to medium families.

\subsubsection{Knowledge on Binasail}

The knowledge on Binasail of the Binasail rice farmers of the study area ranged from 10 to 16 scores against the possible score 0 to 20 . The mean and standard deviation were 13.76 and 1.16, respectively. Data presented in Table 8 show that most (59\%) of farmers had medium knowledge, while $14 \%$ had low knowledge and $27 \%$ had high knowledge. The reason might be that, $67 \%$ of the respondents belonged to "Illiterate" to "Primary education" which was earlier observed. They are likely to have actively involved in farming matters. Moreover, a farmer who received high level of education but was less involved in farming might posses lower agricultural knowledge than the farmers who were actively involved in farming for a long period of time.

\subsubsection{Farm Size}

The highest proportion (78\%) of the farmers had medium farm compared to $12 \%$ having small farm and $10 \%$ having large farm. Thus most (90\%) of the farmers were in the categories of small and medium farms (Table 8 ). Land is the most important capital to a farmer and the farm size has influence on many innovation decision issues including adoption of innovations. Therefore, Government extension development agencies and non-governmental organizations (NGOs) should pay attention to take program for small and medium farm holders on the priority basis because these two categories were combinedly the major portion of the farmers of the study area.

\subsubsection{Annual Income}

Actual annual income (USD) of the respondent Binasail farmers of the study area ranged from 684 to 1258 with mean and standard deviation being 77565.09 and 8500.08 . A major proportion $(79 \%)$ of the farmers belonged to medium income group compared as $10 \%$ having low and $11 \%$ high-income group. They earned from different sources including agriculture, service, business etc. because BAU and Mymensingh towns are very near to the study area, which facilitated for higher income. The finding provides a retinal ground for the adoption of high cost technologies for maximum agricultural production as well as maximum profit.

\subsubsection{Contact with BS}

Data presented in Table 8 reveal that the highest proportion (56\%) of the farmers of the study area had medium contact, while $23 \%$ had high contact and $21 \%$ had low contact with BS. Therefore, a high majority (77\%) of the farmers were under medium and low contact with BS.

\subsubsection{Contact with BINA Personnel}

According to the farmers' contact with BINA personnel, they were classified into two categories as shown in Table 8 . A total of $72 \%$ of the farmers had some contact with BINA personnel, while $28 \%$ of them had no contact. The reason might be that there was a big communication gap between the BINA personnel and the respondent farmers, which represents a gloomy picture.

\subsubsection{Contact with BAUEC Personnel}

Binasail rice farmers' contact with BAUEC personnel of the study area ranged from 0 to 7 against possible score 0 to 20 . The mean and standard deviation were 1.01 and 1.26 , respectively. Total $60 \%$ of the farmers had some contact with BAUEC personnel, while $40 \%$ of them had no contact (Table 8). It happened due to lack of communication gap between the BAUEC personnel and the respondent farmers. However, this situation is far from satisfactory.

\subsubsection{Group Contact}

Data presented in Table 8 indicate that the highest proportion (72\%) of the farmers of the study had the low contact with group methods and $16 \%$ had very low contact. However, only $12 \%$ of the farmers had medium 
group contact. Such a situation presents an adverse trend as far as the group contact of the farmers in the study area of concern.

\subsubsection{Mass Contact}

According to the farmers mass contact scores, they were classified into three categories as shown in Table 8 . Mass contact of the Binasail rice farmers of the study area ranged from 5 to 22 against the possible score 0 to 25 . The mean and standard deviation were 9.16 and 2.95, respectively. A total of $68 \%$ of the farmers of the study had the medium contact as compared to $27 \%$ having low contact. Only $5 \%$ of the farmers had high mass contact. Thus, such a situation also represents an adverse situation, which is far from satisfactory.

\subsubsection{Cosmopoliteness}

The highest proportion (65\%) of the farmers had medium cosmopoliteness as compareted to $20 \%$ having low cosmopoliteness and $15 \%$ high cosmopolitenss. The data also revealed that majority $(85 \%)$ of the farmers were under low to medium categories (Table 8).

\subsubsection{Organizational Participation}

Data furnished in Table 8 show that the highest proportion $(66 \%)$ of the farmers had low participation as compared to $18 \%$ having medium participation and $16 \%$ very low participation. The findings indicate that the majority (84\%) of the farmers of the study area exhibited low to medium organizational participation.

\subsubsection{Opinion Leadership}

The computed opinion leadership scores of the Binasail rice farmers ranged from 0 to 28 against the possible score of 0 to 30 . The mean and standard deviation were 6.43 and 4.89 , respectively. The highest proportion (49\%) of the farmers had low opinion leadership as compared to $31 \%$ having very low opinion leadership and $7 \%$ medium participation, while $13 \%$ had no opinion leadership (Table 8 ).

\subsubsection{Attitude towards Binasail}

About three-fourth $(73 \%)$ of the farmers had less favorable attitude as compared to $25 \%$ having substantial favorable attitude and $2 \%$ had unfavorable attitude towards Binasail. Also the majority (98\%) of the farmers of the study area exhibited less unfavorable to substantial favorable attitude towards Binasail (Table 8).

\subsection{Relationship between Attributes of Binasail and Farmers' Adoption and Innovativeness Regarding Binasail}

Relationship between different attributes of Binasail and farmers' Binasail adoption was examined. The coefficient of correlation was computed and shown in Table 9. It was observed that the relative advantage and trialability had significant but observability had highly significant and positive relationship with the adoption of Binasail rice by the farmers. Therefore, it implied that the farmers having higher relative advantage, trialability and observability had a greater tendency for more adoption of Binasail rice. On the other hand, compatibility and complexity of Binasail rice had no significant relationship with the adoption of Binasail rice by the farmers.

In case of innovativeness, relative advantage, compatibility, trialability and observability of Binasail rice had strongly significant relationship with farmers' innovativeness regarding Binasail rice. However, complexity of Binasail rice had a significant and positive relationship with Binasail growers' innovativeness (Table 9). Thus, all these implied that the higher the relative advantage, compatibility complexity, trialability and observability of Binasail rice, the higher the farmers' innovativeness.

Table 9. Relationship between the attributes of Binasail rice and farmers' adoption and innovativeness

\begin{tabular}{|c|c|c|c|c|c|}
\hline \multirow{2}{*}{$\begin{array}{l}\text { Selected attributes of Binasail } \\
\text { (Independent variables) }\end{array}$} & \multicolumn{2}{|c|}{ Captured 'r' values } & \multicolumn{3}{|c|}{ Tabulated 'r' values with df N-2 i.e. 104} \\
\hline & $\begin{array}{c}\text { Adoption } \\
\text { (dependent variable) }\end{array}$ & $\begin{array}{c}\text { Innovativeness } \\
\text { (dependent variable) }\end{array}$ & 0.05 level & 0.01 level & 0.001 level \\
\hline Relative advantage & $0.198^{*}$ & $0.417^{* * *}$ & & & \\
\hline Compatibility & $0.103^{\mathrm{NS}}$ & $0.312^{* *}$ & & & \\
\hline Complexity & $0.069^{\mathrm{NS}}$ & $0.246^{*}$ & 0.190 & 0.248 & 0.314 \\
\hline Trailability & $0.204^{*}$ & $0.316^{* * *}$ & & & \\
\hline Observability & $0.322^{* * *}$ & $0.519^{* * *}$ & & & \\
\hline
\end{tabular}




\subsection{Relationship Between Farmers' Characteristics and Their Adoption of Binasail Rice}

One of the purposes of the present study was to examine the relationships of farmers' selected characteristics with their adoption and innovativeness of Binasail rice. Each of the characteristics constituted independent variables, while the farmers' adoption and innovativeness of Binasail rice was the dependent variables. To explore the relationship between the selected characteristics of the farmers and their adoption and innovativeness of Binasail rice, Pearson's product moment correlation coefficient ' $r$ ' was used. The correlation between the 15 independent variables and the dependent variables are shown in Table 10.

Table 10. Relationship between the farmers' selected characteristics, and their adoption and innovativeness regarding Binasail rice

\begin{tabular}{|c|c|c|c|c|c|}
\hline \multirow{2}{*}{$\begin{array}{l}\text { Selected attributes of Binasail } \\
\text { (Independent variables) }\end{array}$} & \multicolumn{2}{|c|}{ Captured 'r' values } & \multicolumn{3}{|c|}{$\begin{array}{c}\text { Tabulated ' } r \text { ' values with df } \mathrm{N}-2 \\
\text { i.e. } 104\end{array}$} \\
\hline & $\begin{array}{c}\text { Adoption } \\
\text { (dependent } \\
\text { variable) }\end{array}$ & $\begin{array}{c}\text { Innovativeness } \\
\text { (dependent variable) }\end{array}$ & $\begin{array}{l}0.05 \\
\text { level }\end{array}$ & $\begin{array}{l}0.01 \\
\text { level }\end{array}$ & $\begin{array}{l}0.001 \\
\text { level }\end{array}$ \\
\hline Age & $0.355^{* * *}$ & $0.176^{\mathrm{NS}}$ & \multirow{15}{*}{0.190} & \multirow{15}{*}{0.248} & \multirow{15}{*}{0.314} \\
\hline Education & $0.223^{*}$ & $0.305^{* * *}$ & & & \\
\hline Family size & $-0.065^{\mathrm{NS}}$ & $-0.043^{\mathrm{NS}}$ & & & \\
\hline Knowledge on Binasail & $0.069^{\mathrm{NS}}$ & $0.172^{\mathrm{NS}}$ & & & \\
\hline Farm size & $0.449^{* * *}$ & $0.297^{* *}$ & & & \\
\hline Annual income & $0.035^{\mathrm{NS}}$ & $-0.020^{\mathrm{NS}}$ & & & \\
\hline Contact with BS & $0.389^{* * *}$ & $0.256^{* *}$ & & & \\
\hline Contact with BINA personnel & $0.052^{\mathrm{NS}}$ & $0.072^{\mathrm{NS}}$ & & & \\
\hline $\begin{array}{l}\text { Contact with BAUEC } \\
\text { personnel }\end{array}$ & $0.150^{\mathrm{NS}}$ & $-0.027^{\mathrm{NS}}$ & & & \\
\hline Group contact & $0.059^{\mathrm{NS}}$ & $0.107^{\mathrm{NS}}$ & & & \\
\hline Mass contact & $0.229^{*}$ & $0.169^{\mathrm{NS}}$ & & & \\
\hline Cosmopoliteness & $0.493^{* * *}$ & $0.154^{\mathrm{NS}}$ & & & \\
\hline Organizational participation & $0.242^{*}$ & $0.355^{* * *}$ & & & \\
\hline Opinion of leadership & $0.129^{\mathrm{NS}}$ & $0.103^{\mathrm{NS}}$ & & & \\
\hline Attitude towards Binasail & $0.294^{* *}$ & $0.646^{* * *}$ & & & \\
\hline \multicolumn{6}{|l|}{$\overline{\mathrm{NS}}=$ not significant; } \\
\hline \multicolumn{6}{|c|}{${ }^{*}=$ significant at 0.05 level of probability; } \\
\hline \multicolumn{6}{|c|}{${ }^{* *}=$ significant at 0.01 level of probability; } \\
\hline
\end{tabular}

As shown in Table 10, the coefficient of correlations between the concerned variables were computed, which reveals that there were high significant positive relationship within the age, farm size, contact with BS and cosmopoliteness of the respondents and their adoption of Binasail. In case of age and farm size, it indicates that farmers' higher age and larger farm size were more likely to have more adoption (Pathak \& Majumdar, 1992; Ali et al., 1986; Singh \& Rajendra, 1990; Pal, 1995). In addition, education of the respondents, mass contact, organizational participation and attitude towards Binasail had significant relationship with their adoption of Binasail (Pal, 1995). However, there was no significant relationship observed among the adoption of Binasail and their family size, knowledge on Binasail, annual income, contact with BINA and BAUEC personnel, group contact and opinion leadership (Beal \& Sibley, 1967).

In case of innovativeness, there was high significant positive relationship observed among the education of the respondents, organizational participation, attitude towards Binasail and their innovativeness regarding Binasail. 
Therefore, it indicates that farmers higher education were more likely to have more innovativeness. In addition, it could be concluded from Table 10 that there was also positive significant relationship observed among the farm size and contact with BS; and their innovativeness towards Binasail. However, the rest of the attributes of Binasail growers' had no significant relationship with their innovativeness about Binasail.

\subsection{Reasons for Adoption of Binasail Rice}

Binasail rice growers were asked to mention the reasons for cultivating Binasail rice; therefore, ten reasons were identified by the Binasail growers. However, Table 11 shows the reasons that were arranged in rank order on the basis of number of citations.

Among ten different reasons for adoption of Binasail rice, high yield, low cost production, huge straw availability, high market price and easy access to market in the order named were comparatively important. Simple cultivation procedure and opportunity for its cultivation under rain-fed condition facilitated the farmers for its cultivation.

Table 11. Rank order of different reasons for adoption of Binasail rice

\begin{tabular}{|c|c|c|c|}
\hline $\begin{array}{l}\text { Sl. } \\
\text { No. }\end{array}$ & Reasons for adoption & $\begin{array}{l}\text { No. } \\
\text { citation }\end{array}$ & Rank order \\
\hline 1. & Yield per acre is comparatively high than local variety & 24 & 1 \\
\hline 2. & Comparatively production cost is low & 15 & 2 \\
\hline 3. & Huge straw can be harvested from Binasail for fuel purpose & 13 & 3 \\
\hline 4. & Market price is high as Binasail grain is fine & 12 & 4 \\
\hline 5. & Easy marketable & 10 & 5 \\
\hline 6. & Binasail cultivation procedure is very simple & 9 & 6 \\
\hline 7. & It can be cultivated in rain-fed condition & 7 & 7 \\
\hline 8. & Lodging of Binasail is usually not observed & 5 & 8 \\
\hline 9. & Usually no diseases and insect infestation occur in Binasail & 3 & 9 \\
\hline 10. & $\begin{array}{l}\text { Binsaial matures earlier than Nizersail though transplanting time } \\
\text { is same }\end{array}$ & 2 & 10 \\
\hline
\end{tabular}

\section{Conclusions}

The major focus of the present study was to assess the adoption, innovativeness and adopter categorizations regarding Binasail rice variety. Findings and the logical interpretation of their meaning in the light of other relevant facts encouraged the researchers to draw the following conclusions:

(a) The age of the farmers had a significant positive relationship with the adoption of Binasail rice, which indicates that young to middle aged farmers had higher interest to adopt Binasail rice. Thus, it is necessary for the extension workers to focus on greater number of middle aged and young farmers.

(b) The education of the farmers had a significant positive relationship with their adoption of Binasail rice and innovativeness. The literate farmers were found more credible and imperative than illiterate ones. It may, therefore, be concluded that education makes an individual more responsive and more accountable.

(c) There was no significant relationship observed between family size of the farmers and their knowledge on Binasail with their adoption and innovativeness.

(d) Farm size of the farmers had significant positive relationship with their adoption and innovativeness of Binasail rice, which leads to the conclusion that farmer with larger farm size had more favorable decision regarding the adoption and innovativeness of Binasail rice in their farming system.

(e) Annual income, contact with BINA and BAUEC personnel had no relationship with their adoption or innovativeness of Binasail rice.

(f) Farmers' contact with BS makes them more aware about their needs. Thus, famers' contact with BS had a significant positive relationship with their adoption and innovativeness, which means that the 
more the contact with BS, the more adoption and innovativeness it would be.

(g) Mass media contact changes an individual's behavior. The farmers having medium to high mass media contact might be motivated to perform their farming activities properly. The present study found that the farmers who had comparatively medium to high mass media contact had higher adoption of Binasail rice.

(h) The cosmopoliteness of the farmers had positive significant relationship with their adoption of Binasail rice. It helps increasing knowledge of the farmers towards some improved methods and that is why this study found a significant relationship between the concerned variables.

(i) Although the organizational participation of the farmers had positive significant relationship but it actually had no influence in their adoption and innovativeness of Binasail rice.

(j) The respondent farmers in the study area were quite deficient in opinion leadership, which requires more training for leadership development and that would ultimately increase the organizational participation.

(k) The farmers' attitude towards Binasail had a positive significant relationship with their adoption and innovativeness of Binasail rice, which helps to increase more adoption of Binasail technology. This situation is quite favorable for the implementation of agricultural development programs whatever need arises in the study area.

(1) Relative advantage of Binasail rice had significant positive relationship between adoption and innovativeness. It indicates that relative advantages grew interest of the farmers to adopt Binasail rice.

(m) Although compatibility of Binasail rice had no significant relationship with their adoption, it had positive significant relationship with innovativeness. This means that compatibility of Binasail rice had no effect to adopt but it had an effect in innovativeness.

(n) The complexity of the Binasail rice had no significant relationship with their adoption, while complexity had a significant positive relationship with innovativeness. Therefore, complexity of Binasail rice had no influence in their adoption.

(o) Trialability and observability of Binasail rice had positive significant relationship with their adoption and innovativeness of Binasail rice. However, it indicates that farmers of the study area were interested to take new technology after anyone like this. Therefore, trialability and observability had an influence in their adoption and innovativeness of Binasail rice.

\subsection{Recommendations for Further Study}

(a) It is strongly felt that the study of this nature be replicated in other parts of Bangladesh.

(b) This study investigated the relationship of 15 characteristics of the farmers with their adoption and innovativeness. Therefore, it is recommended that further study should be conducted with other variables.

(c) The study showed that there were no significant relationships of family size, knowledge on Binasail, annual income, contact with BINA and BAUEC personnel, group contact and opinion leadership of the farmers with their adoption of Binasail and age, family size, knowledge on Binasail, annual income, contact with BINA and BAUEC personnel, group contact, mass contact, cosmopoliteness and opinion leadership of the farmers with innovativeness. It is therefore, recommended for further research to verify the results.

(d) Similar study may also be replicated in the future for studying major issues emanating from adoption and innovativeness of Binasail among the same population of the present study.

(e) It is recommended that more researches be conducted to investigate behavioral aspects of diffusion of innovation, diffusion effects and consequences of the diffusion of Binasail. The adoption behavior of the Binasail farmers need to be empirically verified.

\section{References}

Ali, K. A., Chowdhury, S. A., Kader, M. A., \& Goni, M. O. (1986). Factors influencing adoption of sugarcane production technologies among the growers of a sugar mill zone. Bangladesh J. Ext. Edu., 1(2), 25-30.

BBS (Bangladesh Bureau of Statistics). (2010). Bangladesh Population Census, Statistics Division, Ministry of Planning, Government of the People's Republic of Bangladesh. 
Beal, G. M., \& Sibley, D. N. (1967). Adoption of agricultural technology by the Indians of Guatemala - A summary. Rural Soc. Report. 62, Department of Rural Sociology and Anthropology, Iowa State University, Ames, Iowa.

BER (Bangladesh Economic Review). (2008). Bangladesh Bureau of Statistics, Ministry of Planning, Government of the People's Republic of Bangladesh.

Bhuiyan, N. I., Paul, D. N. R., \& Jabber, M. A. (2002). Feeding the extra millions by 2025 - Challenges for rice research and extension in Bangladesh. National Workshop on Rice Research and Extension in Bangladesh, Bangladesh Rice Research Institute, Gazipur, Bangladesh.

Lantin, R. (1999). Rice-Post harvest operation. International Rice Research Institute, Philippines.

Pal, S. K. (1995). Adoption of recommended sugarcane cultivation practices by the farmers of two selected centers of north Bengal sugar mills. M.Sc. (Ag. Ext. Edu.) Thesis, Department of Agricultural Extension Education, Bangladesh Agricultural University, Mymensingh, Bangladesh.

Pathak, S., \& Majumdar, A. K. (1992). Multiple regression analysis of adoption behavior of the farmers. Indian J. Ext Edu, 14(3\&4), 45-50.

Rogers, E. M. (1983). Diffusion of innovations (3rd ed.). New York: Free Press.

Singh, S. P., \& Rajendra, A. (1990). A study on adoption of improved sugarcane variety. Indian J. Ext. Edu., 26(1\&2), 110-111. 